\title{
Long space missions, gene therapy, and the vital role of magnesium: a three-pronged plan for the next 50 years
}

This article was published in the following Dove Press journal: International Journal of Nephrology and Renovascular Disease I September 2010

Number of times this article has been viewed

\section{William J Rowe}

Medical University of Ohio, Toledo, $\mathrm{OH}$, USA

\begin{abstract}
Since pharmaceuticals cannot be used in space until liver and kidney dysfunctions are corrected, and with invariable malabsorption, it appears there is no alternative other than to use subcutaneous magnesium $(\mathrm{Mg})$ replacements in the presence of deficiencies and use of gene therapy. I suggest beginning with the correction of as many as four gene deficiencies: atrial natriuretic peptide (ANP), nitric oxide (NO), vascular endothelial growth factor (VEGF), and erythropoietin (EPO), all as well as $\mathrm{Mg}$ related to perfusion and angiogenesis. There is no evidence of significant lunar radiation levels in the absence of a solar storm. It could then be determined whether this has resulted in correction of liver and kidney dysfunction. If this persists, serial additions of gene therapy will be required determining the effect of each individual gene trial on organ function. Microgravity and endothelial gaps with leaks trigger reduced plasma volume. Partial correction by use of a plasma volume substitute and development of a delivery device may reduce complexity of gene therapy. Research would be conducted both on Earth and in microgravity, with the development of subcutaneous pharmaceuticals and $\mathrm{Mg}$, and a space walk-reliable subcutaneous silicon device, given that no replenishable subcutaneous device is presently available. A three-pronged approach provides a plan for the next 50 years: A. complete correction of a Mg deficit; B. partial replacement with plasma volume substitutes, and C. multiple gene factor strategy.
\end{abstract}

Keywords: malabsorption, gene therapy, kidneys, liver, magnesium, microgravity, space flight

The most sacred of the duties of a government [is] to do equal and impartial justice to all its citizens.

—-Thomas Jefferson, 1816.

\section{Introduction}

It has been 50 years since humans ventured into space. Will the next 50 years bring solutions to the vascular hazards resulting from both microgravity and hypokinesia (restricted movements)? Some animals that live all of their lives in caves cannot adjust to living outside the cave. Are humans spared the restrictions of nature? During space flight, the endothelium is vulnerable to injuries complicating oxidative stress mechanisms with inflammation, triggered by catecholamine, angiotensin, and endothelin elevations, along with reductions in magnesium $(\mathrm{Mg})$ ions, atrial natriuretic peptide (ANP), and nitric oxide (NO), with resulting vicious cycles. With impaired angiogenesis secondary to a $\mathrm{Mg}$ deficit, ${ }^{1}$ and with impaired perfusion of the liver and kidneys and, in turn, insufficient metabolism and excretion of pharmaceuticals, how can an acute myocardial
Correspondence: William J Rowe I 485 Bremerton La., Keswick, VA 22947, USA

Tel +I 4349840079

Email rowerun@aol.com 
infarction, for example, be treated after perhaps 20 months of space flight? It has been noted ${ }^{1}$ that the pharmacokinetic and pharmacodynamics of medications may well be influenced by the effects of microgravity, and emphasized the effects of microgravity on blood flow in the liver. During the 438-day Mir mission, the cosmonaut's cyclic guanosine monophosphate (cGMP) was not detectable after five months in space and did not return to premission levels until three months after return from his space flight. cGMP is a second messenger of both NO and ANP. ${ }^{2,3}$ In the presence of dust inhalation, in such habitats as Apollo 15, combined with space flight and endothelial dysfunction/injury, ${ }^{46}$ these factors can lead to extraordinary elevations of stress test hypertension, even in missions of less than two weeks' duration and in the absence of significant exposure to radiation. ${ }^{1}$ Techniques to prevent inhalation of dust in the environment may eventually be successful, first by removing the space suit before entry and backing into the habitat or module. In addition, ultrafine dust particles $(<100 \mathrm{~nm})$ might be removed from the space suit by electrostatic precipitators. Even without dust exposure, very prolonged space flight may lead to renovascular hypertension with evidence of self-limiting proteinuria, impairment in renal concentrating ability, and elevations of serum creatinine. ${ }^{1}$ In addition, with space flight, there is reduced diurnal blood pressure variation which portends kidney disease. Indeed, on earth, the endothelial repair process is somewhat impaired after the age of 30 years, and these repair mechanisms are further impaired with space flight. ${ }^{1,4,5}$ Pharmaceuticals cannot be used, other than for emergencies, because of invariable malabsorption, and potential impairment in hepatic and renal function, so that those in a space flight would not be able to metabolize or excrete pharmaceuticals satisfactorily, if the mission was sufficiently prolonged. Furthermore, at this time, there is no suitable, replenishable, subcutaneous silicon device to administer medications. In addition, some pharmaceuticals deteriorate during space flight, but why this occurs is unknown. Despite decreased sensitivity of serum $\mathrm{Mg}$, it has been reported ${ }^{1}$ that significantly decreased serum $\mathrm{Mg}$ levels $(P<0.0001)$ after shuttle missions. Both too much $^{4}$ and too little ${ }^{5}$ exercise will decrease these $\mathrm{Mg}$ levels. In the early weeks of a mission, there is a $1 \%-2 \%$ loss of bone per month and loss of skeletal muscle mass, both of which are storage sites for $\mathrm{Mg}$, with further loss from malabsorption. $\mathrm{Mg}$ is required for at least 300 enzymatic reactions, including those which metabolize drugs. $\mathrm{Mg}$ is also an antioxidant and calcium blocker. ${ }^{1}$

All the enzymes that metabolize vitamin D require $\mathrm{Mg}$. Vitamin D, which is depleted in space, is required for bone metabolism and protects the cardiovascular system. Since deficiencies of vitamin D occur in one-third to one-half of otherwise healthy adults, and are conductive to elevations of vessel constrictors and in turn, hypertension, variations in vitamin $\mathrm{D}$ levels both prior to and during a mission may account at least partially for the discrepancies in space flight blood pressures. Reductions, no change, and significant elevations of blood pressures have all been reported. ${ }^{1}$ A request through the Freedom of Information Act (FOIA) in 2007 showed that Irwin possibly had endothelial dysfunction prior to his Apollo 15 mission, and that from one month before lift-off, his resting blood pressure was as high as 145/110 mmHg. A subsequent request for FOIA stress test data regarding Conrad (Apollo 12) and Shepard (Apollo 14) was of no value because the National Aeronautics and Space Administration (NASA) was unable to provide sufficient data for comparison with those from Irwin. Furthermore, NASA will only provide data for astronauts who are deceased.

\section{Gene therapy}

Although the entire body is in jeopardy during a space flight, obviously it would be absurd to suggest that for a very long mission, replacement of a large portion of the genome would be required. However, it is reasonable to begin by using gene therapy to correct four deficiencies, ie, ANP, NO, erythropoetin (EPO), and vascular endothelial growth factor (VEGF) ${ }^{7-10}$ the latter being triggered by space flight, with thrombocytopenia and diminished VEGF expression complicating space flight insulin resistance, and $\mathrm{Mg}$ deficit playing a role. ${ }^{1}$ Thrombocytopenia may be induced by platelet adhesions and aggregation, which is prevented by $\mathrm{NO},{ }^{2,10}$ and platelets are the primary source of VEGF. ${ }^{1}$ Red blood cells, which function as antioxidants, are reduced by about $10 \%$ even on short missions, along with invariable dehydration with, in addition, decreased thirst and invariable reductions of plasma volume, for example, which are reduced by $10 \%$ after a nine-day mission. Radiation was not a factor on Apollo missions. ${ }^{11}$ As for gene therapy, a recent editorial suggests that prospects for continuing advancement of gene therapy to wider applications remain strong. ${ }^{12}$ However, it is apparent that because the molecular mechanisms responsible for angiogenesis are very complex, a "multiple factor strategy" will be required. ${ }^{13}$

$\mathrm{Mg}$ deficiency during a space flight plays an important role in renal disease. An experimental $\mathrm{Mg}$ deficiency has been shown to cause hypertrophy of the juxtaglomerular apparatus, resulting in aldosterone secretion, which in turn increases $\mathrm{Mg}$ loss and creates vicious cycles. These vicious cycles can develop from $\mathrm{Mg}$ ion deficits, with resultant catecholamine 


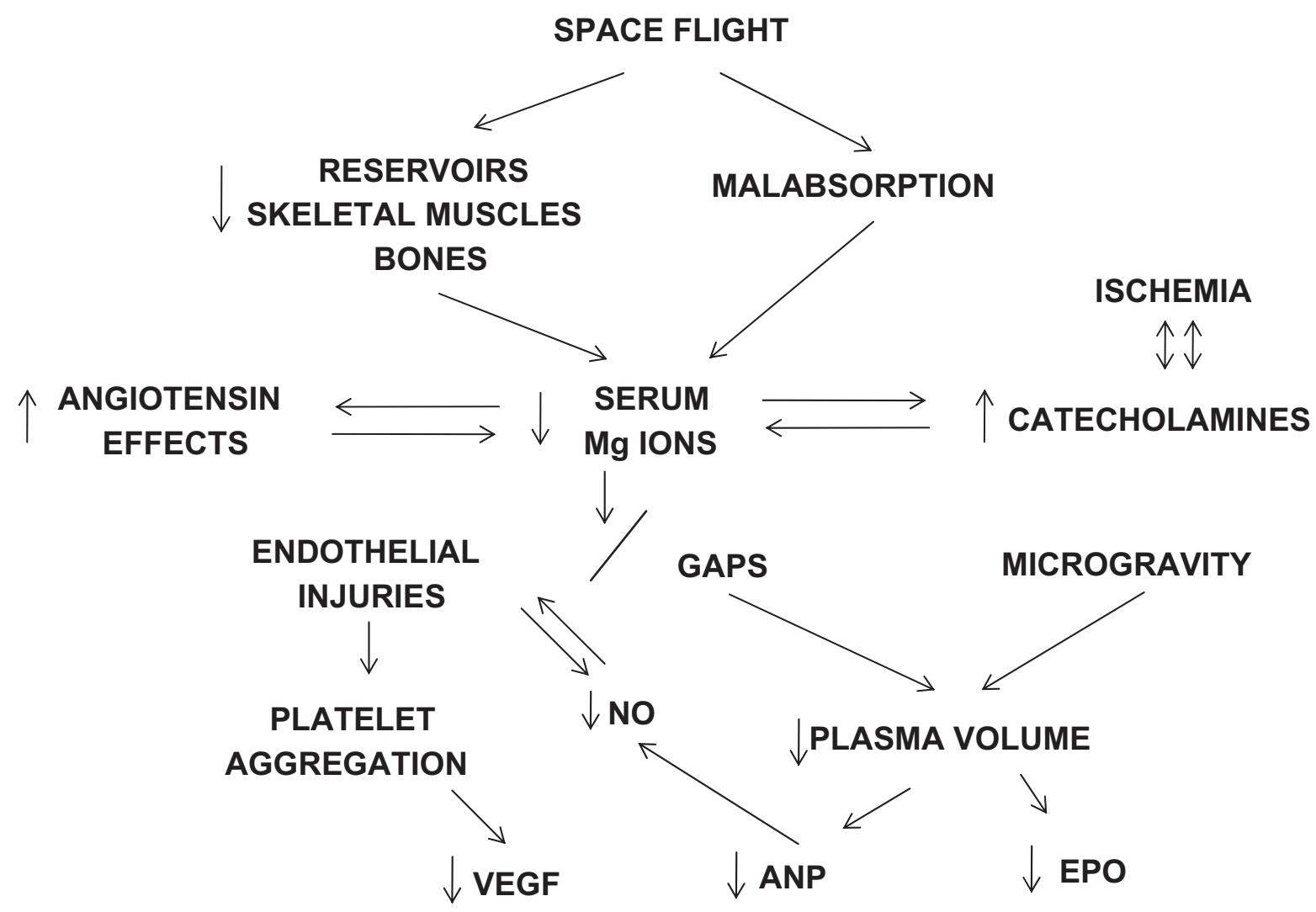

Figure I Proposed mechanisms for space flight-related vascular complications requiring magnesium repacement and possible correction of at least four gene deficiencies. Abbreviations: ANP, atrial natriuretic peptide; EPO, erythropoietin; NO, nitric oxide; VEGF, vascular endothelial growth factor.

elevations and an increased angiotensin effect. The latter can contribute to an upregulated intrarenal renin-angiotensin system with hypertension (see Figure 1). However, if renal insufficiency occurs, $\mathrm{Mg}$ replacement will have to be closely monitored. ${ }^{1}$ Focusing on correction of peripheral vascular complications during space flight, for example, in the presence of a $40 \%$ reduction of calf blood flow in microgravity and doubling of calf vascular resistance, ${ }^{1}$ the results with intramuscular gene transfer of VEGF have been encouraging, with an increase in collateral vessels around the injection sites during a nine-month follow-up study. ${ }^{14,15}$

What has been the space flight experience with delivery of gene therapy systemically? Gene therapy was first suggested a decade ago for treating astronauts with space-induced anemia. ${ }^{16}$ More recent earth-based studies suggest that space flight-gene therapy may be useful for correcting ANP deficiencies of $>40 \%$ after $7-12$ space flight days. ${ }^{1}$ Space flight deficiencies in ANP may play an important role, because on earth, dust inhalation does not cause the degree of hypertension Irwin experienced. ${ }^{17} \mathrm{~A}$ decrease in renal blood flow may be significantly reversed following NO synthase gene transfer, with improvement in renal function. ${ }^{1,10}$ It is clear that with gene therapy we are only at the beginning, with possibly decades of gene therapy research ahead, involving studies both on earth and at the International Space Station. No meaningful research seems to have been conducted with gene therapy to offset the vascular complications of space flight. There are numerous problems with gene therapy, first and foremost, finding a suitable vector. The focus has been primarily in search of a virus vector which would penetrate into the nucleus without causing, eg, immune reactions, severe hypotension, or shock. ${ }^{7,10}$ Transfection efficacy has been found to be only temporary, and there may be pathologic overgrowth of endothelial cells. ${ }^{8}$ Furthermore, McCarthy et a ${ }^{10}$ have emphasized that reproducibility of positive results has yet to be demonstrated conclusively. It is important to stress that there is no evidence from Berry's lunar studies that the various Apollo complications were triggered by significant radiation exposure, ${ }^{11}$ nor is there evidence at this time that the deterioration of some pharmaceuticals during space flight is radiation-related. However, during a solar proton storm the levels would be much higher. On earth, with headdown-tilt bed rest studies, the concentration of cGMP is also decreased. ${ }^{2}$ Therefore, one can assume that the impairment in liver and kidney function may be entirely due to vascular 
insults. ${ }^{1}$ This must be corrected, and pharmaceuticals, other than for symptomatic treatment or emergencies, cannot be administered with any degree of safety.

In cardiac tissue, hypokinesia and space flight studies in experimental animals have shown endothelial projections and narrowing of small vessels with occlusions. ${ }^{1}$ Gaps, with endothelial projections, can cause plasma to leak from vessels. ${ }^{18}$ This intensifies loss of plasma volume from microgravity, beginning soon after lift-off ${ }^{1}$ (see Figure 1). The invariable plasma volume reduction in microgravity triggers anemia associated with reduced EPO levels. ${ }^{19}$ In addition to correcting anemia, EPO may contribute to angiogenesis along with VEGF, NO, ANP, and Mg. ${ }^{1,7-10,13,15,19-21}$ It has been shown that serum EPO, suppressed immediately after launch, remained low during a nine-day shuttle mission. ${ }^{19}$ Correction of EPO deficiency has also been shown to be cardioprotective. However, there is a risk of both hypertension and thrombosis with chronic exposure to EPO gene therapy. ${ }^{21}$

On the other hand, although gene therapy with both NO and ANP can lead to hypotension if the expression of gene therapy is not tightly regulated to the target site, ${ }^{1}$ the risk of inducing shock may be greater with ANP because it directly inhibits the renin-angiotensin-aldosterone axis and the sympathetic nervous system. Because ANP is significantly reduced, partially as a result of reduction in plasma volume, and $\mathrm{Mg}$ is probably necessary for both ANP synthesis and release, this $\mathrm{Mg}$ deficiency must be corrected first, using a yet to be developed subcutaneous silicon device, which can be replenished

Table I Rationale for gene therapy trials, limitations, expected benefits with potential correction of at least four gene deficiencies

\begin{tabular}{|c|c|c|c|}
\hline Gene & $\begin{array}{l}\text { Reason } \\
\text { for reductions }\end{array}$ & Limitations & $\begin{array}{l}\text { Expected } \\
\text { benefits }\end{array}$ \\
\hline \multirow[t]{2}{*}{ ANP } & Reduced PV, cGMP & $\begin{array}{l}\text { Hypotension, } \\
\text { shock }\end{array}$ & Angiogenesis \\
\hline & $\begin{array}{l}\text { Mg required for } \\
\text { release, and possibly } \\
\text { synthesis }\end{array}$ & & $\begin{array}{l}\text { Increased GFR } \\
\text { Decreased BP } \\
\text { Inhibits SNS, RAA }\end{array}$ \\
\hline NO & $\begin{array}{l}\text { Reduced cGMP, } \\
\text { Endothelial injury }\end{array}$ & Hypotension & $\begin{array}{l}\text { Angiogenesis } \\
\text { Prevent platelet A } \\
\text { Antifibrotic } \\
\text { Vasoprotective }\end{array}$ \\
\hline VEGF & $\begin{array}{l}\text { Platelet A } \\
\text { Platelets } \\
\text { primary source }\end{array}$ & $\begin{array}{l}\text { Pathologic } \\
\text { Overgrowth EC }\end{array}$ & $\begin{array}{l}\text { Reduced ischemia } \\
\text { Angiogenesis }\end{array}$ \\
\hline EPO & Reduced PV & $\begin{array}{l}\text { Thrombosis } \\
\text { Hypertension }\end{array}$ & $\begin{array}{l}\text { Increase RBCs } \\
\text { Angiogenesis }\end{array}$ \\
\hline
\end{tabular}

Abbreviations: PV, plasma volume; EC, endothelial cells; GFR, glomerular filtration rate; SNS, sympathetic nervous system; RAA, renin-angiotensin-aldosterone axis; $A$, aggregation; RBCs, red blood cells; EPO, erythropoetin; cGMP, cyclic guanosine monophosphate; VEGF, vascular endothelial growth factor; NO, nitric oxide. and would be reliable during strenuous effort, as with space walks. ${ }^{22}$ It is proposed that, after reversal of a Mg deficit ${ }^{1,22-24}$ it is worthwhile correcting, as a start, deficiencies of as many as four genes, ie, ANP, NO, VEGF, and EPO (see Table 1). If this is successful, as indicated by restoration of both liver and kidney function, subcutaneous pharmaceuticals can be used.

There is limited experience with both subcutaneous $\mathrm{Mg}^{22}$ and subcutaneous pharmaceuticals at this time. These will require research at the International Space Station. If there is still no evidence that organ dysfunction has been offset, then additional genes, specifically those enhancing perfusion, will have to be administered, one by one, and will require decades of research. Because reduced plasma volume is an important trigger for deficiencies of both EPO and ANP, it seems reasonable to postulate that development of a plasma volume substitute ${ }^{25}$ and a subcutaneous delivery device might reduce the complexity of this proposed gene therapy requiring a multifactorial strategy. Furthermore, at least partial restoration of plasma volume may reduce the potential for hypotension and shock (see Table 1). Epstein et $\mathrm{al}^{13}$ have stressed how complicated such a process can be in duplicating angiogenesis, determining the number of factors required, and determining the appropriate sequence and concentration.

Finally, it is conceivable that a centrifuge could be developed which would duplicate exactly $1 \mathrm{G}$ for travel in transit, but the problem would remain of construction of habitats and tunnels, and exploration for long periods on the surface in a microgravity environment. Furthermore, without gene therapy, it seems apparent that man will not be able to colonize the Moon, Mars, an asteroid, or beyond.

\section{Acknowledgment}

Dedicated to the memory of Dr Mildred Seelig, magnesium expert and my mentor.

\section{Disclosure}

The author reports no conflict of interest in this work.

\section{References}

1. Rowe WJ. Potential renovascular hypertension, space missions, and the role of magnesium. Int J Nephrol Renovasc Dis. 2009;2:51-57.

2. Rossler A, Noskov V, Laszlo Z, Polyakow VV, Hinghoffer-Szalkay HG. Permanent depression of plasma cGMP during long-term space flight. Physiol Res. 2001;50:83-90.

3. Costa MA, Elesgaray R, Caniffi C, Fellet A, MacLaughlin M, Arranz C. Role of nitric oxide as a key mediator on cardiovascular actions of atrial natriuretic peptide in spontaneously hypertensive rats. Am J Physiol Heart Circ Physiol. 2010;298:H778-H786.

4. Rowe WJ. Extraordinary unremitting endurance exercise and permanent injury to normal heart. Lancet. 1992;340:712-714.

5. Rowe WJ. Interplanetary travel and permanent injury to normal heart. Acta Astronautica. 1997;40:719-722. 
6. Rowe WJ. The Apollo 15 space syndrome. Circulation. 1998;97: $119-120$

7. Schillinger KJ, Tsai SY, Taffet GE, et al. Regulatable atrial natriuretic peptide gene therapy for hypertension. Proc Natl Acad Sci U SA. 2005; 102:13789-13794.

8. Jin HL, Liu ML, Kim HA, et al. Role of the oxygen-dependent degradation domain in a hypoxia-inducible gene expression system in vascular endothelial growth factor gene therapy. Spine. 2009;34:E952-E958.

9. Rinsch C, Regulier E, Deglon N, Dalle B, Beuzard Y, Aebischer PA. Gene therapy approach to regulated delivery of erythropoietin as a function of oxygen tension. Hum Gene Ther. 1997;8:1881-1889.

10. McCarthy HO, Coulter JA, Robson T, Hirst DG. Gene therapy via inducible nitric oxide synthase: A tool for the treatment of a diverse range of pathological conditions. J Pharm Pharmacol. 2008;60: 999-1017.

11. Berry CA. Medical legacy of Apollo. Aerosp Med. 1974:1046-1057.

12. Kohn DB, Candotti F. Gene therapy fulfilling its promise. $N$ Engl $J$ Med. 2009;360:518-521.

13. Epstein SE, Fuchs S, Zhou YF, Baffour R, Kornowski R. Therapeutic interventions for enhancing collateral development by administration of growth factors: Basic principles, early results and potential hazards. Cardiovasc Res. 2001;49:532-542.

14. Rowe WJ. As with spaceflight, a magnesium deficit may be responsible for both peripheral vascular dysfunction and kidney disease. Am J Cardiol. 2010;105:1203-1204.

15. Kim HJ, Jang SY, Park JI, et al. Vascular endothelial growth factorinduced angiogenic gene therapy in patients with peripheral artery disease. Exp Mol Med. 2004;36:336-344.
16. Ohi S. Developing protocols for recombinant adeno-associated virusmediated gene therapy in space. $J$ Gravit Physiol. 2000;7:67-68.

17. Rowe WJ. Extraordinary hypertension after a lunar mission. Am J Med. 2009;122:e1.

18. McDonald DM, Thurston G, Baluk P. Endothelial gaps as sites for plasma leakage in inflammation. Microcirculation. 1999;6:7-22.

19. de Santo NG, Cirillo M, Kirsch KA, et al. Anemia and erythropoietin in space flights. Semin Nephrol. 2005;25:379-387.

20. Yamahara $\mathrm{K}$, Itoh $\mathrm{H}$, Chun $\mathrm{TH}$, et al. Significance and therapeutic potential of the natriuretic peptides/cGMP/cGMP-dependent protein kinase pathway in vascular regeneration. Proc Natl Acad Sci U S A. 2003;100:3404-3409.

21. Mehta JL. Erythropoietin in cardioprotection: Does it have a future or is it all in the past? Cardiovasc Res. 2008;79:549-550.

22. Rowe WJ. The case for a subcutaneous magnesium product and delivery device for space missions. J Am Coll Nutr. 2004;23:S525-S528.

23. Bernardini D, Nasulewic A, Mazur A, Maier JA. Magnesium and microvascular endothelial cells: A role in inflammation and angiogenesis. Front Biosci. 2005;10:1177-1182.

24. Becking GC. Hepatic drug metabolism in iron-, magnesium-, and potassium-deficient rats. Fed Proc. 1976;35:2480-2485.

25. Lundsgaard-Hansen P, Collins JA, David-West AS, et al. Use of plasma volume substitutes and plasma in developing countries. Bull World Health Organ. 1983;61:7-22.

\section{Publish your work in this journal}

The International Journal of Nephrology and Renovascular Disease is an international, peer-reviewed open-access journal focusing on the pathophysiology of the kidney and vascular supply. Epidemiology, screening, diagnosis, and treatment interventions are covered as well as basic science, biochemical and immunological studies. The journal welcomes original research, clinical studies, reviews \& evaluations, expert opinion and commentary, case reports and extended reports. The manuscript management system is completely online and includes a very quick and fair peerreview system, which is all easy to use. Visit http://www.dovepress.com/ testimonials.php to read real quotes from published authors. 